\title{
International Criminal Justice Review
}

\section{Taking crime seriously: Conservation values and legal cynicism as predictors of public perceptions of the seriousness of crime}

\begin{tabular}{|c|l|}
\hline Journal: & International Criminal Justice Review \\
\hline Manuscript ID & ICJR-OA-18-06-056 \\
\hline Manuscript Type: & Original Article \\
\hline Keywords: & $\begin{array}{l}\text { crime seriousness, perceptions, legal cynicism, conservation values, } \\
\text { religiosity }\end{array}$ \\
\hline Abstract: & $\begin{array}{l}\text { Public perceptions of the seriousness of crime have long been presented as } \\
\text { an indicator of actual crime seriousness, which features prominently in } \\
\text { contemporary criminal policy. However, doubts persists on the policy } \\
\text { relevance of such perceptions, among others, because their predictors and } \\
\text { the extent of consensus about them in our pluralistic societies are unclear. } \\
\text { Against this background, we examine the extent to which conservation } \\
\text { values, legal cynicism and religiosity drive public crime seriousness } \\
\text { perceptions and generate heterogeneity. A general population survey in } \\
\text { Belgium eliciting 1,278 valid responses indicates a limited impact of these } \\
\text { values, attitudes and beliefs on crime seriousness perceptions, with } \\
\text { exception of the "mala prohibita" considered. Of the three predictors, } \\
\text { conservation values have the most consistent impact across different } \\
\text { crimes. Coupled with the limited relevance of the controls, these findings } \\
\text { suggest a high level of consensus among the public in its ratings of crime } \\
\text { seriousness. }\end{array}$ \\
\hline
\end{tabular}




\title{
Taking crime seriously: Conservation values and legal cynicism as predictors of public perceptions of the seriousness of crime
}

\begin{abstract}
Public perceptions of the seriousness of crime have long been presented as an indicator of actual crime seriousness, which features prominently in contemporary criminal policy. However, doubts persists on the policy relevance of such perceptions, among others, because their predictors and the extent of consensus about them in our pluralistic societies are unclear. Against this background, we examine the extent to which conservation values, legal cynicism and religiosity drive public crime seriousness perceptions and generate heterogeneity. A general population survey in Belgium eliciting 1,278 valid responses indicates a limited impact of these values, attitudes and beliefs on crime seriousness perceptions, with exception of the "mala prohibita" considered. Of the three predictors, conservation values have the most consistent impact across different crimes. Coupled with the limited relevance of the controls, these findings suggest a high level of consensus among the public in its ratings of crime seriousness.
\end{abstract}

\section{Keywords:}

Crime seriousness, perceptions, legal cynicism, conservation values, religiosity

\section{Introduction}

Since Sellin and Wolfgang's (1964) landmark study, a large body of literature has developed on public perceptions of the seriousness of crime. Drawing on these studies, many scholars 
and practitioners consider public crime seriousness perceptions an important indicator of actual crime seriousness, which features prominently in at least four areas of contemporary criminal policies (i.e., sentencing, criminalization, crime control and prevention; see Adriaenssen et al., 2018). Robinson and Darley (2007), for example, conclude that the public can give nuanced and sophisticated assessments of offence seriousness (and offender's blameworthiness) and contend that only such "empirical deserts" can guarantee the legitimacy and moral credibility of crime control policies among the wider public. Even more forcefully, Tonry (2015: 665) claims that "citizens' rankings of the seriousness of crime tell us all we need to know for purposes of sentencing and corrections policy."

These positions reflect the growing relevance of public opinion in criminal policy since the advent of systematic surveys (Ryberg and Roberts, 2014). Public perceptions are also seen as a means to address the continuous decline of public trust in policing and criminal justice in western democracies (Karstedt, 2013). Hence, for example, the sentencing guidelines of England and Wales (see Sentencing Guidelines Council, 2004) account for public perceptions of crime seriousness and the Belgian police (Charlier et al., 2006) explicitly factor public concern for different crimes into their methodology to establish longterm priorities.

Other scholars, however, highlight the risk of excessively relying on public opinion in criminal policy deliberations (e.g., Roberts, 2011). They point to several limitations of public perceptions, including knowledge deficits, factual misjudgment a lack of reflection on the criteria for evaluating known facts, and volatility. The warning that Rossi and Henry (1980: 500) formulated in the first review of the literature on crime seriousness perceptions is also still valid: "without ... (a) clear ... understanding of how seriousness judgments are made, it would be hazardous to run the criminal justice system by looking to crime seriousness as a 
guide" (see Stylianou, 2003: 48). Moreover, when using public opinion on crime seriousness as a benchmark, the problem of agreement or disagreement among the public arises. If disagreement is widespread, criminal policies relying on such perceptions run the risk of alienating wide parts of the public and of failing to secure confidence in criminal justice. Although previous research found a high level of consensus (see Stylianou, 2003 and Robinson and Kurzban, 2007), differences are likely to have grown in recent decades, reflecting the increasing diversity of the public in contemporary western democracies, and the growing differences in their cultural backgrounds and frames.

This study addresses the latter two issues. Drawing on an innovative conceptualization of crime seriousness (see Adriaenssen et al., 2018), we examine the extent to which value patterns, attitudes and beliefs drive public crime seriousness perceptions and thus generate heterogeneity. Specifically, we consider the relevance of conservation values (Schwartz, 1994; Schwartz et al., 2012), legal cynicism (Sampson and Bartusch, 1998), and religiosity (Newman, 1976). Our analyses are based on data from a survey of a sample of Flemish citizens (Dutch-speaking citizens in Belgium) conducted in 2014.

\section{Understanding public perceptions of crime seriousness}

In this section, we first present the components of perceived crime seriousness. Second, we consider the issue of diversity among the public. Third, we examine the attitudes, values and beliefs that have so far been used as correlates of crime seriousness perceptions.

\section{The components of perceived crime seriousness}

Warr (1989) was the first to explicitly conceptualize perceived crime seriousness. He identifies two main components, "wrongfulness" and "harmfulness." The former results 
from "a normative evaluation" of the "moral gravity of committing the act," while the latter is assessed through "a factual assessment of the consequences of the offence upon the victim" (p. 796). Warr's (1989) Dallas survey and two later studies (O'Connell and Whelan, 1996; Rosenmerkel, 2001) empirically backed this conceptualization.

More recently, Adriaenssen et al. (2018) extended Warr's (1989) concept of harmfulness, building on Greenfield and Paoli's (2013) harm assessment framework. They conceptualized seriousness in terms of 1 ) the wrongfulness of a crime, defined as the severity of the violation of moral norms and sentiments implied by a criminal activity, 2) the severity of the harms of a crime, defined as the gravity of the injury or damage that the crime inflicts, 3) the incidence of the crime, defined as the frequency with which this type of crime actually happens, and 4) the incidence of the harms of a crime, defined as the frequency with which a type or range of harms occurs. Their findings show that only wrongfulness and harm severity are related to perceived crime seriousness, with the former exceeding the weight of the latter in determining seriousness. These results mirror those of O'Connell and Whelan (1996) as well as Alter et al. (2007) who find that people emphasize the wrongfulness over the harmfulness of crime in assessing crime seriousness. They also limit the usefulness of public perceptions for policy-making purposes, given that actual crime seriousness is understood as consisting of the harm done or risked by the act and the offender's culpability, with no reference to the wrongfulness of the activity (Ashworth, 2006).

\section{Consensus and difference in public perceptions of crime seriousness}

Empirical research investigating crime seriousness perceptions has consistently found considerable agreement among respondents on the ranking of crimes (see Stylianou, 2003). 
Hawkins $(1981)$ and Miethe $(1982,1984)$ were the first to specifically analyze the high level of consensus on rankings of crime seriousness between otherwise often widely differing social groups. Miethe (1984) termed this phenomenon "relative consensus." ${ }^{1}$ Reviewing earlier studies, Robinson and Kurzban (2007: 1892) conclude that a sense of relative seriousness of the "core wrongs - physical aggression, takings without consent and deception in exchanges" is widely shared and deeply engrained. Generally, crimes resulting in physical injury are ranked as the most serious crimes, followed by property crimes and "victimless" crimes (e.g., prostitution and homosexuality; Rossi et al., 1974; Wolfgang et al., 1985) and/or "morals offences" (e.g. drug use, adultery, homosexuality, prostitution and gambling; Evans and Scott, 1984). As consensus has been found also cross-culturally (see Stylianou, 2003), Eisner at al. (2017) argue that universal intuitions about wrongdoing shape a cross-cultural consensus on a set of core crimes protecting physical integrity and property, and that the seriousness rankings mirror intuitions about the perceived extent of inflicted harm.

In order to explain variation beyond consensus, most studies analyze sociodemographic characteristics (e.g., gender, age, socio-economic status, educational level and ethnicity; see Stylianou, 2003). A few also consider victimization experiences (e.g., Adriaenssen et al., 2018 Rosenmerkel, 2001; Wolfgang et al., 1985), generally finding that victimization does not impact seriousness ratings for most crimes.

\section{Attitudes and beliefs associated with crime seriousness perceptions}

As noted by Rossi and Henry (1980) and Stylianou (2003), there has been limited research on

\footnotetext{
${ }^{1}$ Miethe (1984) also defines absolute consensus, which refers to agreement about scores rather than about rankings, but mainly uses measures of relative consensus.
} 
the attitudes associated with crime seriousness perceptions. Only two attitudinal constructs have been confirmed in previous studies as strong predictors: authoritarianism ${ }^{2}$ (e.g., Feather, 1996) and dogmatism ${ }^{3}$ (Fleming, 1981). Both attitudinal patterns indicate a lawand-order mentality and an orientation that favors control by social and legal institutions and the conservation of the existing moral order, as well as a rejection of diversity and deviancy. Religiosity ${ }^{4}$ has also been identified as a predictor of crime seriousness ratings, and Newman (1976) deems it a major predictor particularly in cross-national studies. Evans and Scott (1984) find that religiosity is a strong predictor for the seriousness of "morals offences"; in contrast, violent, property and white-collar offences are perceived similarly by respondents with different scores on religiosity. ${ }^{5}$

\section{Conceptual framework and hypotheses}

Our conceptualization of perceived crime seriousness draws on Adriaenssen et al. (2018), but only takes on board the two components that have proven to be statistically significant: perceived crime wrongfulness and perceived harm severity, the latter corresponding to

\footnotetext{
${ }^{2}$ Authoritarianism is defined as "an orientation [that favors] subjection to the control and hegemony of powerful social and legal institutions and is opposed to individual autonomy and normative diversity" (Mentor and Dorne, 1998: 77).

${ }^{3}$ Dogmatism refers to a rigid way of thinking and intolerance of alternative beliefs. Someone scoring high on this attitude "evaluates other people in terms of the apparent compatibility of their beliefs with his own" (Fleming, 1981: 55).

${ }^{4}$ Religiosity has been conceptualized in different ways (e.g., intensity of religious belief, church attendance, frequency of praying, donating money to church activities; see Aleksynska \& Chiswick, 2013; Billiet, n.d.).

${ }^{5}$ Evans and Scott (1984) do not explicitly define religiosity (as separate from religious fundamentalism).
} 
Warr's (1989) conceptualization of harmfulness. We use two value/attitudinal patterns as predictors that have proven to have heuristic value in criminology and other social sciences, but have not yet been considered in this field: conservation values relating to the social order and its norms, and legal cynicism relating to legal norms proper. In addition we include religiosity.

Conservation values are one of the dimensions of Basic Human Values identified by Schwartz and his colleagues (see Schwartz, 1994; Schwartz et al., 2012). In both theory and cross-cultural research, they identify ten motivationally distinct types of values that are likely to be recognized within and across cultures: power, achievement, hedonism, stimulation, self-direction, universalism, benevolence, tradition, conformity, and security. These values are organized in a circular structure with four clusters and two contrasting poles: these are self-transcendence versus self-enhancement, and conservation versus openness to change. Conservation values include tradition, conformity and security. Tradition values emphasize the customs and ideas of one's culture and religion; conformity values imply subordination to institutions and more abstract principles; security values include safety, harmony and stability for the self and society. In general, conservation values refer to the wish "to preserve the status quo and the certainty it provides" (Schwartz and Boehnke, 2004: 236).

The second attitudinal pattern, "legal cynicism," comprises attitudes towards the law. The concept was developed by Sampson and Bartush (1998) and describes a state of anomia. It refers to "the sense that laws are not considered binding in the existential, present lives of respondents" and to the "ratification of acting in ways that are outside of laws and social norms" (Sampson and Bartush, 1998: 786). Kirk and Papachristos (2011) see legal cynicism as a cultural frame in which people perceive the law as illegitimate, unresponsive and ill equipped to ensure public safety. Legal cynicism has proven to be related to violence levels 
and arrest rates in neighborhoods (Kirk and Matuseda, 2011; Kirk and Papachristos, 2011).

Research at the individual level has found a strong, negative relation between legal cynicism and the perceived legitimacy of criminal justice agencies (e.g., Reisig et al., 2011).

We hypothesize that those who hold conservation values will deem the disruption to the social order by crime generally as more serious; they will in particular base this judgment on the violation of the moral order, but also on the disturbance of the social equilibrium through the harm done to the innocent, and/or the inappropriate and unfair gains for the perpetrator. ${ }^{6}$ In contrast, legal cynics will rate the seriousness of crimes generally as less serious. They will base their judgment foremost on the irrelevance of the moral order, and second, on belittling the harm that has been done; they might also consider the unfair gains for the perpetrator as less important, thus resulting in generally lower ratings for seriousness. We also consider religiosity, which we understand as the intensity of religious belief (see Billiet, n.d.; Newman, 1976) and hypothesize that religiosity will have a similar impact as conservation values.

Following Evans and Scott (1984), Robinson and Kurzban (2007) and Eisner et al. (2017), we also assume that both attitudinal frames and religiosity will affect the ratings for violent, property and fraud offences less than those concerning drug offences. Whereas the former are "core wrongs" (Robinson and Kurzban, 2007), the latter are mala prohibita and be considered representative of Evans and Scott's (1984) "morals offences."

We test the following hypotheses:

\footnotetext{
${ }^{6}$ Unfair gains for the perpetrator are seen as driving evolutionary cognitive emotional processes on which moral and justice intuitions are built (Eisner et al., 2017).
} 
H1: Individuals with higher conservation values and higher levels of religiosity rate crimes generally as more serious, with corresponding higher scores for both perceived wrongfulness and harm severity.

H2: Individuals with higher legal cynicism rate crimes generally as less serious, with corresponding lower scores for both perceived wrongfulness and harm severity.

H3: Conservationism, legal cynicism and religiosity have less impact on ratings of violent, property and fraud offences than those concerning drug offences.

\section{Methods}

\section{Sample and survey}

A stratified sample from each of the five Flemish provinces was drawn by the Belgian National Register, which records data on all Belgian residents. The National Register first randomly selected six ZIP codes in each of the five provinces, giving a higher probability to ZIP codes with a larger number of inhabitants. Subsequently, it randomly selected 50 adult male and 50 adult female, Dutch-speaking inhabitants from each ZIP code, generating a representative sample of 3,000 Dutch-speaking adults across the different Flemish provinces. ${ }^{7}$ The National Register sent the questionnaires, with a cover letter and response envelope to the selected adults. All questionnaires were identical, with the same ordering of

\footnotetext{
${ }^{7}$ We pre-tested the survey quantitatively and qualitatively. The quantitative pre-test, a questionnaire filled in by 160 first year criminology students, focused on the scales and their reliability. For the qualitative pre-test, we interviewed 15 individuals, using the technique of cognitive interviewing (Willis, 2005).
} 
questions and items. ${ }^{8}$ A reminder was sent after three weeks. Out of 1,297 questionnaires returned (43.2\%), we retained 1,278 for the analysis, resulting in a response rate of $42.6 \%$. According to the recent literature, such rate is acceptable (Pickett et al., 2018; Tourangeau, 2017).

\section{Variables}

a) Crime seriousness, wrongfulness and harm severity We selected ten crimes for the survey on the basis of several criteria: i.e., differences in the perceived seriousness of the crimes as established by previous studies (see Stylianou, 2003); the sentences meted by the Belgian criminal law and the crime incidence; representation of crimes against the person and property; representation of individual as well as corporate and collective offences; and the incidence with which they are shown on Flemish TV. Respondents were asked to consider four crimes against persons (murder, physical assault, sexual assault and terrorism), three crimes against property (burglary, theft, vandalism), one fraud (corporate fraud) and two drug offences (cocaine trafficking and cannabis trade). For the purpose of this paper, we categorize the first eight as representing core wrongs (Robinson and Kurzban, 2007) and the two drug offences mala prohibita/morals offences. (Evans and Scott, 1984). For the description of each crime, we used the offence scenario method (e.g., Sellin and Wolfgang, 1964; Warr, 1989). The scenario for theft was, for example, "a person intentionally steals another person's properties." Through such brief descriptions, the scenario method avoids the opposite risks of either letting respondents "fill

${ }^{8}$ As an incentive, five vouchers from a multimedia store, three vouchers for a dinner for two in a famous Flemish restaurant and an iPad mini were set as prizes for participation. 
in the blanks" (Lynch and Danner, 1993) or asking them to assess a specific scenario, rather than a general crime category.

We asked respondents three questions for each of the offences, covering the two components of wrongfulness and harm severity as well as overall seriousness. ${ }^{9}$ We used the categorical scaling method (see Stylianou, 2003 for overview, and Kwan et al., 2000 for criticisms) and two types of questions to assess the severity of harm. For the crimes of burglary, physical assault and cocaine trafficking, we used a list of items covering concrete examples of possible harms for individuals, private entities, government and society. We asked respondents: "How severe do you consider this harm for the [crime]?" Answer categories ranged from no harm at all to very severe harm on a 5-point scale. For each of the three crimes, we constructed a scale based on the mean scores on the different aspects of harm (Cronbach's $\alpha=.695$ for physical assault; $\alpha=.667$ for burglary and $\alpha=.738$ for cocaine trafficking). For the seven other crimes, we asked one general question on the severity of the crime harms, but instructed the respondents to consider different types and bearers of harm in their assessment of severity of crime harms as they had done previously for the three crimes. The question was: "As the preceding questions show that crime-related harm can include physical injuries and financial losses as well as financial costs for the government and feelings of unsafety, indicate how severe you think the total harm for the following crimes in Belgium." ${ }^{10}$

${ }^{9}$ The questionnaire also included two other questions on , the incidence of crimes and the incidence of the harms in relation to the crimes, which are not discussed here (see BLINDED).

${ }^{10}$ As the scores were sufficiently robust for all three crimes, we use them in the same way as the more simplified measurement of harm severity. Even if this method might result in slightly higher or lower scores (which we cannot check), the overall ranking of these 
Wrongfulness for each of the crimes was measured using questions developed by Warr (1989) and Wikström et al. (2012); we asked respondents to rate "how wrong or bad [they] think it is, if somebody commits this crime" on a 9-point scale ranging from not at all wrong to very wrong. Overall seriousness was also rated on a 9-point scale, ranging from not serious at all to very serious. We instructed respondents to reflect on the components of seriousness by asking: "Taking into account the crime wrongfulness, the severity of its harms and the incidence of the crime and its harms, how serious do you think the following crimes are?" After constructing the scales as described above, all scales were transformed into 100point scales for the analyses.

b) Conservation values, legal cynicism and religiosity Conservation values were measured by the "Conformity," "Security" and "Tradition" subscales of the "Human Values Scale," as available in the European Social Survey (see Schwartz et al., 2012). Each of these subscales is measured via two items. ${ }^{11}$ After the pretest, we removed one of the "Tradition" items. An exploratory factor analysis showed that the remaining five items loaded on one factor, explaining $40.27 \%$ of the variance; the resulting scale "conservationism" had a Cronbach's alpha of .766. Legal cynicism was measured by a slightly adapted version of Sampson and crimes among the other seven crimes demonstrates that these two methods can be used simultaneously (see BLINDED).

${ }^{11}$ The original measurement was changed after pre-tests. The original measurement of the Human Values Scale asks the respondent to indicate how much a characteristic of a person is (not) like him or her on a 6-point scale ranging from very much like me to not like me at all. In our survey we asked respondents how much they agreed with the statement on a 5-point scale. 
Bartusch's (1998) original scale. In that scale, respondents are asked to report their level of agreement with five statements "assessing general beliefs about the legitimacy of law and social norms" (Sampson and Bartusch, 1998: 786), on a 5-point scale ranging from strongly disagree to strongly agree. Following pre-test results and exploratory factor analysis, we retained only three items (Cronbach's $\alpha=.599$ ): "Laws were made to be broken"; "It's okay to do anything you want as long as you don't hurt anyone"; "To make money, there are no right and wrong ways anymore, only easy ways and hard ways." These three items loaded on one factor, explaining $34.06 \%$ of the variance.

Religiosity was measured by the following question from the European Social Survey (2010): "Regardless of whether you belong to a particular religion, how religious would you say you are?" to which subjects responded on a 5-point scale from not religious at all to very religious.

\section{c) Control variables}

We used seven demographic variables as controls: gender; age; socio-economic status (5point scale consisting of seven items, $\alpha=.929$; educational level (five categories, dummycoded as none/primary/secondary education vs. high school/university) and country of origin of the respondent and of both parents (dummy-coded as Belgian or non-Belgian origin). In addition, we included victimization experiences as controls. We asked respondents about their victimization experience during the past five years ${ }^{12}$ : whether they had personally been a crime victim (direct victimization; yes/no) or whether one of their friends,

\footnotetext{
${ }^{12}$ We chose a period of five years to capture less and more serious incidents of victimization. Recall periods of five years have been used e.g., in the European Social Survey (2004) for victimization of crimes of everyday life (Karstedt, 2015).
} 
families, neighbors or acquaintances had been a crime victim (indirect victimization; yes/no). Respondents answered these questions for six of the ten crimes, i.e., assault, sexual assault, burglary, theft, vandalism and corporate fraud. Based on the data for these questions, we constructed overall direct and indirect victimization measures; in the following analyses both types of victimization are used as dummy variables.

\section{Analyses}

We conducted ordinary least squares regression analyses. ${ }^{13}$ We present models for perceived seriousness, wrongfulness and harm severity for each of the ten crimes. The first model contains the three independent variables; the second model also includes the control variables, including victimization. ${ }^{14}$

\section{Results}

Table 1 gives an overview over the sample characteristics. Compared to the general population, ${ }^{15}$ our sample is representative for gender, but not age $(p<.05)$ or education

\footnotetext{
${ }^{13}$ We detected no major problems, testing for the assumptions of normality, linearity, heteroscedasticity, multicollinearity and outliers, except for some crimes (e.g. murder, physical assault and terrorism). As the independent variables are only weakly to moderately correlated with each other (see below), we do not anticipate problems due to multicollinearity. Linear regression is robust for violation against normality and homoscedasticity requirements (Voeten and Van den Bercken, 2003); we have used the same techniques and approach for all crimes in order to achieve comparable results.

${ }^{14}$ We ran models that used general /overall as well as crime-specific victimization for the six crimes only. As the results did not differ, we only use models that include general victimization.

${ }^{15}$ The official statistics for the Flemish population are available at http://statbel.fgov.be/nl/statistieken/cijfers/bevolking/loop/.
} 
$(p<.05)$. People under the age of 34 are underrepresented (sample: $22 \%$; population: $25.6 \%)$, whilst those between 50 and 64 are overrepresented (sample: 29.4\%; population: $25.3 \%$ ). Similarly, persons with lower educational levels (none, primary and secondary education) are underrepresented (sample: 56.7\%; population: 71.9\%), whilst high school students are overrepresented (sample: 31.2\%; population: 17.8\%). Eighty-six percent of the respondents are of Belgian origin. More than half of the respondents (56.8\%) have experienced personal victimization. Four fifth of the respondents have had indirect victimization experiences (79.4\%).

[Table 1 about here]

The mean scores for the perception variables range from $81.75(S D=22.84)$ to 99.52 $(S D=3.96)$ for crime seriousness, from $84.52(S D=21.25)$ to $99.54(S D=3.29)$ for crime wrongfulness and from $66.67(S D=21.56)$ to $94.04(S D=13.49)$ for harm severity; the highest means are found for murder, the lowest for cannabis trade (for an overview of the scores for all offences, see BLINDED). As regards values, attitudes and beliefs, we find the following mean scores : $3.80(S D=0.65)$ for conservation values, 2.20 for legal cynicism $(S D=$ 0.72 ) and $2.80(S D=1.11)$ for religiosity. These values, attitudes and beliefs are weakly to moderately correlated. As expected, conservation values are positively related to religiosity $(r=.257 ; p<.001)$, and negatively to legal cynicism $(r=-.138 ; p<.001)$, while there is no relationship between religiosity and legal cynicism. Furthermore, men are more cynical with regard to law (male=2.24; female: $2.16 ; \mathrm{t}=2.05 ; \mathrm{p}<.05$ ) and women see themselves as more religious (male=2.72; female: $2.88 ; t=-2.53 ; p<05$ ); there are no differences for conservation values. Older people adhere more to conservation values $(r=.337 ; p<.001)$ and see 
themselves as more religious $(r=.264 ; p<.001)$. Legal cynicism is held independent of age. Generally, those with less education and lower socio-economic status have significantly higher levels of conservation values (education: $r=-.122 ; p<.001 ;$ SES: $r=.086 ; p<.05$ ), legal cynicism (education: $r=-.222 ; p<.001$; SES: $r=-.162 ; p<.001$ ), and religiosity (education: $r=-$ $.114 ; p<.001 ;$ SES: $r=-.167 ; p<.001)$. Both direct and indirect overall victimization coincides with significantly less legal cynical attitudes (direct: no victim=2.25; victim=2.16; $t=2.063 ; p<$ .05 ; indirect: no victim=2.32; victim=2.17; $t=2.73 ; p<.01$ ). While there are no differences between Belgians and individuals with a non-Belgian background with regard to conservation values and legal cynicism, non-Belgians see themselves as more religious (nonBelgian:=2.96; Belgian=2.77; $t=-2.06 ; p<.05)$.

We test our hypotheses with models for perceived wrongfulness, harm severity and overall seriousness of each of the ten crimes. In tables 2-4, we present the models separately. For wrongfulness (table 2), we find little impact of values, attitudes and beliefs on the group of violent crimes. Legal cynics only see sexual violence and terrorism as less wrongful, whereas those with higher levels of conservation values regard physical assault as more wrongful. In contrast, we find significant effects of conservation values on the perceived wrongfulness of the three property crimes (i.e., theft, burglary, and vandalism). Neither legal cynicism nor religiosity have any impact. In the case of corporate fraud, both legal cynicism and religiosity contribute to the perceived wrongfulness. Legal cynics deem it as less wrongful, whereas religious individuals tend to see this crime as more morally wrong.

For the two drug offences, both conservation values and religiosity are related to perceived wrongfulness: higher levels of moral condemnation coincide with more conservation values, as well as with a higher degree of religiosity. In contrast, legal cynicism coincides with lower ratings of wrongfulness, however a significant relationship is only found 
for cannabis trade. Cannabis trade is the only crime for which we find an impact for all three factors, and in the predicted direction, with the highest level of explained variance $\left(R^{2}=\right.$ .174). This is a highly contested offence and subject to political debates, not only in Belgium, but in many countries. The results for perceived wrongfulness, thus, indicate d differences among the offences. Even if small, conservation values have the most consistent impact on the wrongfulness ratings across all crimes.

[Table 2 about here]

A similar picture emerges for the models concerning the harm severity ratings (table 3). Conservation values have the most consistent impact. Again, among violent crimes, an impact is only found for physical assault. Religiosity is a determining factor of perceived harm severity only for the drug offences. In no instance, legal cynicism is related to harm severity assessments when adding the control variables to the models. Legal cynics do not discard the harms of crime, or rate them as less serious, even if they rate crimes as less wrongful (e.g., sexual assault or corporate fraud).

[Table 3 about here]

For overall seriousness (table 4), the pattern of impact of the three factors mirrors the preceding findings for wrongfulness and harm severity. ${ }^{16}$ Conservation values have the

\footnotetext{
${ }^{16}$ We ran models for seriousness that included the other two dimensions, wrongfulness and harm severity. The results did not differ from the ones reported in
} 
most consistent and highest impact across all property and drug offences. Among the four violent offences, a relationship is only found for physical assault. In contrast, legal cynicism and religiosity have consistently no predictive power, neither for violence, nor for property crimes. The exception mirrors the one found for the wrongfulness ratings: legal cynics rate the seriousness of sexual assault lower. Corporate fraud is equally rated as less serious by legal cynics and as more serious by religious individuals; conservation values do not impact the rating of seriousness of this crime. All three factors, however, determine the seriousness ratings of the two drug offences. Tradition, security and conformity orientations increase the seriousness ratings, as does religiosity. In contrast, legal cynicism decreases the seriousness ratings.

[Table 4 about here]

The contribution of conservation values, legal cynicism and religiosity to the explained variance remains limited; this applies to all three dependent variables. In general, they explain less than $5 \%$ of the variance in crime wrongfulness and harm severity ratings, and between $5 \%$ and $10 \%$ of the variance in crime seriousness ratings. Hence, consensus is high, although it differs between the different categories of crimes. As expected, the ratings of the two drug offences are most affected by differences in values, attitudes and beliefs, with the explained variances ranging from $7.2 \%$ to $19.1 \%$.

The effects of the controls are also small, again indicating consensus among the different groups. However, gender has a consistent effect on the three dependent variables, BLINDED, and demonstrate that perceived wrongfulness and harm severity in most cases override the other variables (not shown here). 
with women rating all crimes, with the exception of theft and burglary, as more wrong/harmful/serious than men. Age is relevant for wrongfulness and seriousness perceptions for almost all offences; however, it only has an effect on the harm severity ratings of sexual assault, vandalism and corporate fraud. The effects are all positive, with the exception of sexual assault, which is perceived as less wrong/harmful/serious by older people. Harm severity and seriousness assessments for almost all offences are affected by socio-economic status; in contrast, only the wrongfulness assessments of theft, corporate fraud and cannabis trade are. The effects are all negative, with lower assessments for people with higher socio-economic status. Educational level has an effect on the wrongfulness judgments of only one offence (theft), on the harm severity ratings of four offences (murder, sexual assault, terrorism, and vandalism) and on the seriousness assessments of five offences (the three property offences and the two drug offences). The effects are negative, with lower ratings for higher educated people. Origin has no effect on the ratings of any offence.

Indirect victimization experiences are only relevant for the wrongfulness of burglary, whereas it has no effect for the other offences or harm severity/seriousness assessments. Direct victimization experiences are not related to wrongfulness judgements, but have an effect on the harm severity and seriousness ratings of three offences each (harm severity: physical assault, burglary and cocaine trafficking; seriousness: sexual assault, theft and cocaine trafficking). The effects are positive, but small, with victims having higher ratings.

\section{Discussion}

Our results generally support our hypotheses, but qualify all three. With regard to $H 1$, we find that individuals with higher conservation values and higher levels of religiosity rate 
crimes generally as more serious, more wrongful and more harmful. As conservation values and religiosity are only moderately correlated, they cover different orientations underlying crime seriousness assessments. What individuals with high conservation orientation might consider a severe violation and disturbance of the social order, religious individuals might regard as a violation of a faith-based moral order, independent of the faith itself.

For $\mathrm{H} 2$, we find that where legal cynicism has an impact at all, legal cynics rate crimes generally as less serious and wrongful. In contrast to our expectations, we find no impact of legal cynicism on harm severity assessments. Legal cynics do not discard or diminish the harm done by crimes, but they rate several crimes as less wrongful and therefore as less serious. These crimes include two violent crimes - sexual assault and terrorism - , corporate fraud and the drug offences. As regards the two violent offences, one explanation might be that legal cynics sympathize more with the offender than with the victim. Further studies, though, must clarify how legal cynicism can function as a technique of neutralization and justification of violence, as proven by Kirk and Papachristos (2011) and others, independent on the latter's perceived harmfulness (see Nivette et al., 2017). As for corporate fraud, our findings are not surprising because our scenario of this offence ${ }^{17}$ addresses legal cynical attitudes directly, in particular that "there are no right and wrong ways anymore, only easy ways and hard ways [to make money]." We hypothesize that legal cynics consider drug offences as less serious, because they see them as victimless crimes and behaviors that are only restricted by law without no embedding in a moral order.

Our findings also partially support $\mathrm{H} 3$ that conservation values, legal cynicism and religiosity have less impact on ratings for violent, property and fraud than drug offences.

${ }^{17}$ The scenario was defined as "The head of a company manipulates repeatedly over the years the company's accounting." 
Generally, these values, attitudes and beliefs explain a higher level of variance for the latter than for the former; this applies to all three types of perceptions. The most consistent impact across crimes is found for conservation values: we found their impact on the ratings concerning physical assault, all three property crimes, and the two drug offences. Whereas the impact on drug offences was expected, the impact on the former offences was not anticipated. It might be due to the fact that physical assault and property crimes represent serious disturbances of the moral and social order that target victims directly and visibly. As such they are "signal crimes" (Innes, 2014) for the decay and failure of the moral and social order. Individuals with high conservation orientation might, therefore, rate such disturbances as both morally wrong and harmful to individuals and communities.

\section{Conclusion}

Our study has been intended to assess the extent to which conservation values, legal cynicism and religiosity drive public perceptions of crime seriousness and promote their heterogeneity. It has some obvious limitations: it is based on a small number of crimes (ten) and a regional survey in a rather homogenous population (Flanders), a relatively low response rate as well as a sample with some biases (age, education), thus raising questions of generalizability. Nonetheless, with these caveats in mind, we address each aim, in turn.

Our results indicate some impact of values, attitudes and beliefs on crime perceptions; however, their exploratory power remains limited, with the exception of what we have termed mala prohibita or morals offences. Of the three predictors, conservation values have the most consistent impact across different crimes. Coupled with the limited relevance of the controls, our findings suggest a high level of consensus among the public in its ratings of the seriousness of crime. Especially for the core wrongs, the ratings are mostly 
consensual between social groups that differ on other matters. As such, the assessments of the core wrongs may be considered "moral intuitions" (Haidt, 2007) that are widely shared between people, societies and cultures.

Our findings thus allay one concern about the reliance on public crime seriousness perceptions as an indicator of actual crime seriousness in policy-making, even if they do not sweep away the other concerns discussed in the literature (e.g., Roberts, 2011; Adriaenssen et al., 2018). They also raise the question of how to reconcile these shared perceptions with the widely differing attitudes concerning reactions to crime and punitiveness and the resulting, hugely different systems of criminal justice that have emerged historically and cross-culturally (see, e.g., Whitman, 2003 and Roberts et al., 2003 for historical and contemporary analyses, respectively).

\section{References}

Adriaenssen A, Paoli L, Karstedt S, Visschers J, Greenfield VA and Pleysier P (2018) Public perceptions of the seriousness of crime: Weighing the harm and the wrong. European Journal of Criminology. doi: 10.1177/1477370818772768

Aleksynska M and Chiswick BR (2013) The determinants of religiosity among immigrants and the native born in Europe. Review of Economics of the Household 11(4): 563-598.

Alter AM, Kernochan J and Darley JM (2007) Transgression wrongfulness outweighs its harmfulness as a determinant of sentence severity. Law and Human Behavior 31(4): 319-335.

Ashworth A (2006) Principles of criminal law. Oxford: Oxford University Press.

Billiet J (n.d.) Proposal for questions on religious identity: European Social Survey Core Questionnaire Development. Retrieved from 
$\underline{\text { www.europeansocialsurvey.org/index.php?option=com content\&view=article\&id=6 }}$

\section{$\underline{2 \& \text { Itemid }=355}$}

Charlier R, Dickens C, Olbrechts C, Pattyn M, Savenberg S, Vanhyfte C and Wouters P (2006) Nationaal politieel veiligheidsbeeld - Image policière nationale de sécurité. Brussels: Federale Politie.

Eisner M, Murray AL, Ribeaud D, Averdijk M and Gelder JL (2017) From the savannah to the magistrate court: The roots of criminal justice in evolved human psychology. In: Jann B and Przepiorka W (eds) Social Dilemmas, institutions, and the evolution of cooperation. Berlin: de Gruyter, pp. 61-84.

Evans SS and Scott JE (1984) The seriousness of crime cross-culturally: The impact of religiosity. Criminology 22(1): 39-59.

Feather NT (1996) Reactions to penalties for an offense in relation to authoritarianism, values, perceived responsibility, perceived seriousness, and deservingness. Journal of Personality and Social Psychology 71(3): 571-587.

Fleming S (1981) The closed mind and the judgement of crime: A replication of the SellinWolfgang index. International Journal of Comparative and Applied Criminal Justice 5(1): 51-64.

Greenfield VA and Paoli L (2013) A framework to assess the harms of crimes. British Journal of Criminology 53(5): 864-885.

Haidt J (2007) The new synthesis in moral psychology. Science 316(5827): 998-1001. Hawkins DF (1981) Causal attribution and punishment for crime. Deviant Behavior 2(3): 207230.

Innes M (2014) Signal crimes: Reactions to crime and social control. Oxford: Oxford University Press. 
Karstedt S (2015) Charting Europe's moral economies: Citizens, consumers and the crimes of everyday life. In: Van Erp J, Huisman W and Vande Walle G (eds) The Routledge handbook of white-collar and corporate crime. London: Routledge, pp. 57-88.

Karstedt S (2013) Trusting authorities: Legitimacy, trust and collaboration in non-democratic regimes. In: Tankebe J and Liebling A (eds) Legitimacy and criminal justice: An international exploration. Oxford: Oxford University Press, pp. 127-156.

Kirk DS and Matsueda M (2011) Legal cynicism, collective efficacy and the ecology of arrest. Criminology 49(2): 443-471.

Kirk DS and Papachristos AV (2011) Cultural mechanisms and the persistence of neighborhood violence. American Journal of Sociology 116(4): 1190-1233.

Kwan YK, Ip WC and Kwan P (2000) A crime index with Thurstone's scaling of crime severity. Journal of Criminal Justice 28(3): 237-244.

Lynch JP and Danner MJ (1993) Offense seriousness scaling: An alternative to scenario methods. Journal of Quantitative Criminology 9(3): 309-322.

Mentor KW and Dorne CK (1998) The association between right-wing authoritarianism and perceived seriousness of deviant acts: A research note. Deviant Behavior 19(1): 7387.

Miethe TD (1982) Public consensus on crime seriousness: Normative structure or methodological artifact? Criminology 20(3-4): 515-526.

Miethe TD (1984) Types of consensus in public evaluations of crime: An illustration of strategies for measuring "consensus." The Journal of Criminal Law and Criminology 75(2): 459-473.

O'Connell M and Whelan A (1996) Taking wrongs seriously. British Journal of Criminology 36(2): 299-318. 
Newman GR (1976) Comparative deviance: Perception and law in six cultures. New York: Elsevier.

Nivette AE, Eisner M, Malti T and Ribeud D (2015) The social and developmental antecedents of legal cynicism. Journal of Research in Crime and Delinquency 52(3): 270-298.

Pickett JT, Cullen FT, Bushway, SD Chiricos T and Alpert G (2018) The response rate test: Nonresponse bias and the future of survey research in criminology and criminal justice. The Criminologist 43(1): 7-11.

Reisig MD, Wolfe SE and Holtfreter K (2011) Legal cynicism, legitimacy, and criminal offending: The nonconfounding effect of low self-control. Criminal Justice and Behavior 38(12): 1265-1279.

Roberts JV (2011) The future of state punishment: The role of public opinion in sentencing. In: Tonry M (ed) Retributivism has a past. Has it a future? Oxford: Oxford University Press, pp. 101-129.

Roberts J, Stalans L, Indermaur D and Hough M (2003) Penal populism and public opinion. Oxford: Oxford University Press.

Robinson PH and Kurzban R (2007) Concordance and conflict in intuitions of justice. Minnesota Law Review 91: 1829-1907.

Robinson PH and Darley JM (2007) Intuitions of justice: Implications for criminal law and justice policy. Southern California Law Review 81(1): 1-68.

Rosenmerkel SP (2001) Wrongfulness and harmfulness as components of seriousness of white-collar offenses. Journal of Contemporary Criminal Justice 17(4): 308-327.

Rossi PH and Henry PH (1980) Seriousness: A measure for all purposes? In: Klein MW and Teilmann KS (eds) Handbook of criminal justice evaluation. Thousand Oaks: Sage, pp. 489-505. 
Rossi PH, Waite E, Bose CE and Berk RE (1974) The seriousness of crimes: Normative structure and individual differences. American Sociological Review 39(2): 224-237.

Ryberg J and Roberts JV (2014) Popular punishment: On the normative significance of public opinion. New York. Oxford University Press.

Sampson RJ and Bartusch J (1998) Legal cynicism and (subcultural?) tolerance of violence:

The neighborhood context of racial differences. Law \& Society Review 32(4): 777-804.

Schwartz SH (1994) Are there universal aspects in the structure and contents of human values? Journal of Social Issues 50(4): 19-45.

Schwartz MD and Boehnke K (2004) Evaluating the structure of human values with confirmatory factor analysis. Journal of Research in Personality 38(3): 230-255.

Schwartz SH, Vecchione M, Fischer R, Ramos A et al. (2012) Refining the theory of basic individual values. Journal of Personality and Social Psychology 103(4): 663-688.

Sellin T and Wolfgang M (1964) The measurement of delinquency. Montclair: Patterson Smith.

Sentencing Guidelines Council (2004) Overarching principles: Seriousness - guidelines. London: Sentencing Guidelines Council.

Stylianou S (2003) Measuring crime seriousness perceptions: What have we learned and what else do we want to know. Journal of Criminal Justice 31(1): 37-56.

Tonry M (2015) The fog around cost-of-crime studies may finally be clearing. Criminology \& Public Policy 14(4): 653-671.

Tourangeau R (2017) Presidential address: Paradoxes of nonresponse. Public Opinion Quarterly 81(3): 803-814.

Voeten MJ and Van den Bercken JH (2003) Lineaire regressieanalyse. Groningen: WoltersNoordhof. 
Warr M (1989) What is the perceived seriousness of crimes? Criminology 27(4): 795-822.

Whitman JQ (2003) Harsh justice. Oxford: Oxford University Press.

Wikström P-OH, Oberwittler D, Treiber K and Hardie B (2012) Breaking rules: The social and situational dynamics of young people's urban crime. Oxford: Oxford University Press.

Willis GB (2005) Cognitive interviewing: A tool for improving questionnaire design. Thousand Oaks: Sage.

Wolfgang M, Figlio RM, Tracy PE and Singer SJ (1985) National Survey of Crime Severity. Washington: Government Printing Office. 
1

2

3

4

5

6

7

8

9

10

11

12

13

14

15

16

17

18

19

20

21

22

23

24

25

26

27

28

29

30

31

32

33

34

35

36

37

38

39

40

41

42

43

44

45

46

47

48

49

50

51

52

53

54

55

56

57

58

59

60

\begin{tabular}{|c|c|c|c|}
\hline Variable & $N$ & $\%$ & $M(S D)$ \\
\hline \multicolumn{4}{|l|}{ Gender } \\
\hline Male & 597 & 47.0 & \\
\hline Female & 672 & 53.0 & \\
\hline Age & & & $49.94(17.03)$ \\
\hline SES & & & $3.58(0.85)$ \\
\hline \multicolumn{4}{|l|}{ Education } \\
\hline No higher & 712 & 57.7 & \\
\hline Higher & 522 & 42.3 & \\
\hline \multicolumn{4}{|l|}{ Origin } \\
\hline Belgian & 1077 & 86.4 & \\
\hline Non-Belgian & 169 & 13.6 & \\
\hline \multicolumn{4}{|l|}{ Victimization } \\
\hline \multicolumn{4}{|l|}{ Direct } \\
\hline Yes & 719 & 56.8 & \\
\hline No & 546 & 43.2 & \\
\hline \multicolumn{4}{|l|}{ Indirect } \\
\hline Yes & 1008 & 79.4 & \\
\hline No & 261 & 20.6 & \\
\hline
\end{tabular}


Table 2. Values, attitudes and beliefs as predictors of crime wrongfulness perceptions (standardized regression coefficients)

\begin{tabular}{|c|c|c|c|c|c|c|c|c|c|c|}
\hline & \multicolumn{2}{|c|}{ Murder } & \multicolumn{2}{|c|}{ Physical assault } & \multicolumn{2}{|c|}{ Sexual assault } & \multicolumn{2}{|c|}{ Terrorism } & \multicolumn{2}{|c|}{ Theft } \\
\hline & M1 & M2 & M1 & $\mathrm{M} 2$ & M1 & $\mathrm{M} 2$ & M1 & $\mathrm{M} 2$ & M1 & $\mathrm{M} 2$ \\
\hline \multicolumn{11}{|l|}{ Predictors } \\
\hline Conservation & .049 & .028 & $.153^{* * *}$ & $.107^{* *}$ & -.037 & .008 & .029 & .032 & $.202 * * *$ & $.151^{* * *}$ \\
\hline Legal cynicism & .025 & .039 & $-.077^{*}$ & -.058 & $-.155 * * *$ & $-.135 * * *$ & $-.083 *$ & $-.077^{*}$ & .018 & -.022 \\
\hline Religiosity & .073 & .064 & .005 & -.020 & -.063 & -.048 & -.032 & -.030 & -.018 & -.057 \\
\hline \multicolumn{11}{|l|}{ Control variables } \\
\hline Gender $(0=$ man $)$ & & $.106^{* *}$ & & $.146 * * *$ & & $.107^{* *}$ & & .065 & & .061 \\
\hline Age & & .065 & & $.156 * * *$ & & $-.110 * *$ & & .007 & & $.114^{* *}$ \\
\hline SES & & .051 & & -.016 & & -.053 & & .042 & & $-.084^{*}$ \\
\hline $\begin{array}{l}\text { Education ( } 0=\text { no higher } \\
\text { education) }\end{array}$ & & .027 & & .076 & & .053 & & -.021 & & $-.128 * *$ \\
\hline Origin (0=Belgian) & & .045 & & -.040 & & .005 & & .036 & & -.059 \\
\hline \multicolumn{11}{|l|}{ Victimization $(0=\mathrm{no})$} \\
\hline Direct victim & & -.040 & & -.022 & & .074 & & .018 & & .028 \\
\hline Indirect victim & & -.020 & & .036 & & .055 & & .039 & & .058 \\
\hline Adjusted $R^{2}$ & .005 & .018 & .030 & .067 & .023 & .056 & .005 & .003 & .034 & .073 \\
\hline \multirow[t]{4}{*}{ F Change } & 2.297 & $2.256 *$ & $8.261^{* * *}$ & $4.979 * * *$ & $6.683^{* * *}$ & $4.474 * * *$ & 2.101 & 0.862 & $9.421 * * *$ & $5.253 * * *$ \\
\hline & \multirow{2}{*}{\multicolumn{2}{|c|}{ Burglary }} & \multirow{2}{*}{\multicolumn{2}{|c|}{ Vandalism }} & \multirow{2}{*}{\multicolumn{2}{|c|}{ Corporate fraud }} & & & \multirow{2}{*}{\multicolumn{2}{|c|}{ Cannabis trade }} \\
\hline & & & & & & & \multicolumn{2}{|c|}{ Cocaine trafficking } & & \\
\hline & M1 & $\mathrm{M} 2$ & M1 & $\mathrm{M} 2$ & M1 & $\mathrm{M} 2$ & M1 & $\mathrm{M} 2$ & M1 & $\mathrm{M} 2$ \\
\hline \multicolumn{11}{|l|}{ Predictors } \\
\hline Conservation & $.153^{* * *}$ & $.121 * *$ & $.194 * * *$ & $.126 * *$ & $.099 *$ & .048 & $.194 * * *$ & $.147^{* * *}$ & $.293 * * *$ & $.223^{* * *}$ \\
\hline Legal cynicism & -.046 & -.065 & .005 & -.011 & $-.110^{* *}$ & $-.124^{* *}$ & -.060 & -.072 & -.060 & $-.085 *$ \\
\hline Religiosity & -.031 & -.052 & $.083^{*}$ & .040 & $.122 * *$ & $.084^{*}$ & $.136 * * *$ & $.104^{* *}$ & $.217 * * *$ & $.167^{* * *}$ \\
\hline \multicolumn{11}{|l|}{ Control variables } \\
\hline Gender (0=man) & & .017 & & $.100 * *$ & & $.121^{* *}$ & & $.123^{* * *}$ & & $.158^{* * *}$ \\
\hline Age & & $.100 *$ & & $.192^{* * *}$ & & $.123^{* *}$ & & $.115^{* *}$ & & $.151^{* * *}$ \\
\hline SES & & -.031 & & -.056 & & $-.088^{*}$ & & -.033 & & $-.086 *$ \\
\hline $\begin{array}{l}\text { Education ( } 0=\text { no higher } \\
\text { education) }\end{array}$ & & -.069 & & -.039 & & -.013 & & -.040 & & -.057 \\
\hline Origin (0=Belgian) & & -.037 & & -.054 & & -.012 & & -.022 & & -.034 \\
\hline \multicolumn{11}{|l|}{ Victimization $(0=$ no $)$} \\
\hline Direct victim & & .051 & & .027 & & -.034 & & .070 & & .005 \\
\hline Indirect victim & & $.083^{*}$ & & .052 & & .030 & & -.032 & & -.048 \\
\hline Adjusted $R^{2}$ & .022 & .037 & .049 & .088 & .044 & .071 & .075 & .097 & .174 & .227 \\
\hline F Change & $6.317^{* * *}$ & $2.612 *$ & $13.069 * * *$ & $5.429 * * *$ & $11.870 * * *$ & $3.987^{* * *}$ & $20.076 * * *$ & $3.544 * * *$ & $50.929 * * *$ & $7.937 * * *$ \\
\hline
\end{tabular}

Note. $N$ was 711 for each of the crimes; ${ }^{*} p<.05,{ }^{* *} p<.01,{ }^{* * *} p<.001$. 
Table 3. Values, attitudes and beliefs as predictors of harm severity perceptions of crime (standardized regression coefficients)

\begin{tabular}{|c|c|c|c|c|c|c|c|c|c|c|}
\hline & \multicolumn{2}{|c|}{ Murder } & \multicolumn{2}{|c|}{ Physical assault } & \multicolumn{2}{|c|}{ Sexual assault } & \multicolumn{2}{|c|}{ Terrorism } & \multicolumn{2}{|c|}{ Theft } \\
\hline & M1 & $\mathrm{M} 2$ & M1 & M2 & M1 & $\mathrm{M} 2$ & M1 & M2 & M1 & M2 \\
\hline \multicolumn{11}{|l|}{ Predictors } \\
\hline Conservation & $.090 *$ & .059 & $.186^{* * *}$ & $.185^{* * *}$ & .007 & .023 & .014 & -.015 & $.158^{* * *}$ & $.144^{* * *}$ \\
\hline Legal cynicism & .053 & .006 & -.003 & -.009 & -.024 & -.042 & .060 & .021 & -.053 & -.071 \\
\hline Religiosity & $.085^{*}$ & .053 & -.037 & -.051 & .028 & .023 & $.104 * *$ & .076 & .000 & -.015 \\
\hline \multicolumn{11}{|l|}{ Control variables } \\
\hline Gender ( $0=$ man $)$ & & .048 & & $.123 * *$ & & $.136^{* * *}$ & & $.078 *$ & & .040 \\
\hline Age & & .003 & & -.021 & & $-.104 *$ & & .003 & & .024 \\
\hline SES & & $-.125^{* *}$ & & $-.108 * *$ & & -.077 & & $-.087^{*}$ & & -.070 \\
\hline $\begin{array}{l}\text { Education ( } 0=\text { no } \\
\text { higher education) }\end{array}$ & & $-.113^{* *}$ & & -.002 & & $-.086^{*}$ & & $-.111^{* *}$ & & -.057 \\
\hline Origin ( $0=$ Belgian) & & .022 & & -.053 & & -.017 & & .027 & & -.060 \\
\hline \multicolumn{11}{|l|}{ Victimisation $(0=$ no $)$} \\
\hline Direct victim & & -.036 & & $.095^{*}$ & & .036 & & -.002 & & .064 \\
\hline Indirect victim & & -.064 & & -.034 & & -.036 & & -.063 & & .027 \\
\hline Adjusted $R^{2}$ & .016 & .051 & .029 & .058 & -.003 & .032 & .010 & .035 & .026 & .037 \\
\hline \multirow[t]{3}{*}{ F Change } & $4.805^{* *}$ & $4.750 * * *$ & $7.673 * * *$ & $4.013 * * *$ & 0.393 & $4.584 * * *$ & $3.410^{*}$ & $3.583 * * *$ & $7.350 * * *$ & $2.078^{*}$ \\
\hline & \multicolumn{2}{|c|}{ Burglary } & \multicolumn{2}{|c|}{ Vandalism } & \multicolumn{2}{|c|}{ Corporate fraud } & \multicolumn{2}{|c|}{ Cocaine trafficking } & \multicolumn{2}{|c|}{ Cannabis trade } \\
\hline & M1 & $\mathrm{M} 2$ & M1 & $\mathrm{M} 2$ & M1 & $\mathrm{M} 2$ & M1 & $\mathrm{M} 2$ & M1 & $\mathrm{M} 2$ \\
\hline \multicolumn{11}{|l|}{ Predictors } \\
\hline Conservation & $.221^{* * *}$ & $.203^{* * *}$ & $.223 * * *$ & $.176^{* * *}$ & $.144^{* * *}$ & $.096 *$ & $.204 * * *$ & $.184^{* * *}$ & $.221 * * *$ & $.186^{* * *}$ \\
\hline Legal cynicism & -.004 & -.026 & $.077^{*}$ & .038 & .007 & -.025 & .064 & .030 & .028 & -.017 \\
\hline Religiosity & .019 & -.006 & $.076^{*}$ & .036 & .050 & .007 & $.144^{* * *}$ & $.101^{* *}$ & $.161 * * *$ & $.117^{* *}$ \\
\hline \multicolumn{11}{|l|}{ Control variables } \\
\hline Gender ( $0=$ man $)$ & & .072 & & $.079 *$ & & .045 & & $.144 * * *$ & & $.074 *$ \\
\hline Age & & .042 & & $.099 *$ & & $.101^{*}$ & & .022 & & .034 \\
\hline SES & & $-.083^{*}$ & & $-.098 *$ & & $-.158 * * *$ & & $-.183 * * *$ & & $-.180 * * *$ \\
\hline $\begin{array}{l}\text { Education ( } 0=\text { no } \\
\text { higher education) }\end{array}$ & & -.052 & & $-.105^{* *}$ & & -.016 & & -.020 & & -.068 \\
\hline Origin ( $0=$ Belgian) & & -.002 & & -.011 & & .018 & & .051 & & .049 \\
\hline \multicolumn{11}{|l|}{ Victimisation $(0=$ no $)$} \\
\hline Direct victim & & $.122 * *$ & & .052 & & -.015 & & $.092 *$ & & .062 \\
\hline Indirect victim & & -.005 & & .021 & & .009 & & -.044 & & -.068 \\
\hline Adjusted $R^{2}$ & .048 & .068 & .060 & .092 & .022 & .051 & .072 & .130 & .088 & .137 \\
\hline F Change & $12.217^{* * *}$ & $3.090 * *$ & $15.767 * * *$ & $4.514^{* * *}$ & $6.415^{* * *}$ & $4.014 * * *$ & $18.294 * * *$ & $7.284 * * *$ & $23.630 * * *$ & $6.717^{* * *}$ \\
\hline
\end{tabular}


Table 4. Values, attitudes and beliefs as predictors of crime seriousness perceptions (standardized regression coefficients)

\begin{tabular}{|c|c|c|c|c|c|c|c|c|c|c|}
\hline & \multicolumn{2}{|c|}{ Murder } & \multicolumn{2}{|c|}{ Physical assault } & \multicolumn{2}{|c|}{ Sexual assault } & \multicolumn{2}{|c|}{ Terrorism } & \multicolumn{2}{|c|}{ Theft } \\
\hline & M1 & M2 & M1 & $\mathrm{M} 2$ & M1 & $\mathrm{M} 2$ & M1 & $\mathrm{M} 2$ & M1 & $\mathrm{M} 2$ \\
\hline \multicolumn{11}{|l|}{ Predictors } \\
\hline Conservation & .054 & .024 & $.209 * * *$ & $.138 * * *$ & .025 & .054 & .013 & .020 & $.260 * * *$ & $.182^{* * *}$ \\
\hline Legal cynicism & -.008 & -.006 & -.062 & -.071 & $-.080^{*}$ & $-.083^{*}$ & -.069 & -.067 & .015 & -.034 \\
\hline Religiosity & $.079 *$ & .059 & .064 & .012 & -.003 & -.004 & -.014 & -.016 & .059 & -.003 \\
\hline \multicolumn{11}{|l|}{ Control variables } \\
\hline Gender ( $0=$ man $)$ & & $.082 *$ & & $.174 * * *$ & & $.102 * *$ & & $.093 *$ & & .052 \\
\hline Age & & $.094^{*}$ & & $.204^{* * *}$ & & $-.089 *$ & & -.009 & & $.192 * * *$ \\
\hline SES & & -.004 & & $-.091 *$ & & $-.083^{*}$ & & .009 & & $-.132 * * *$ \\
\hline $\begin{array}{l}\text { Education ( } 0=\text { no higher } \\
\text { education) }\end{array}$ & & .021 & & .011 & & -.011 & & -.026 & & $-.104^{* *}$ \\
\hline Origin ( $0=$ Belgian) & & .057 & & .008 & & .018 & & .073 & & .009 \\
\hline \multicolumn{11}{|l|}{ Victimization $(0=n o)$} \\
\hline Direct victim & & -.004 & & .046 & & $.105^{* *}$ & & .027 & & $.106^{* *}$ \\
\hline Indirect victim & & .009 & & .037 & & .021 & & .057 & & .020 \\
\hline Adjusted $R^{2}$ & .007 & .014 & .059 & .121 & .003 & .032 & .001 & .010 & .074 & .143 \\
\hline \multirow[t]{3}{*}{ F Change } & $2.767^{*}$ & 1.626 & $15.780 * * *$ & $7.978 * * *$ & 1.811 & $3.961 * * *$ & 1.234 & 1.865 & $19.697 * * *$ & $8.962 * * *$ \\
\hline & \multicolumn{2}{|c|}{ Burglary } & \multicolumn{2}{|c|}{ Vandalism } & \multicolumn{2}{|c|}{ Corporate fraud } & \multicolumn{2}{|c|}{ Cocaine trafficking } & \multicolumn{2}{|c|}{ Cannabis trade } \\
\hline & M1 & M2 & M1 & $\mathrm{M} 2$ & M1 & $\mathrm{M} 2$ & M1 & $\mathrm{M} 2$ & M1 & $\mathrm{M} 2$ \\
\hline \multicolumn{11}{|l|}{ Predictors } \\
\hline Conservation & $.254 * * *$ & $.200 * * *$ & $.267 * * *$ & $.179 * * *$ & $.142 * * *$ & .071 & $.207^{* * *}$ & $.141^{* * *}$ & $.308 * * *$ & $.228 * * *$ \\
\hline Legal cynicism & .006 & -.029 & .018 & -.020 & -.055 & $-.082^{*}$ & -.066 & $-.098 * *$ & -.049 & $-.086 *$ \\
\hline Religiosity & .016 & -.027 & $.092 *$ & .030 & $.155^{* * *}$ & $.099 * *$ & $.164^{* * *}$ & $.110 * *$ & $.232 * * *$ & $.172^{* * *}$ \\
\hline \multicolumn{11}{|l|}{ Control variables } \\
\hline Gender ( $0=$ man $)$ & & .040 & & $.119 * * *$ & & $.136^{* * *}$ & & $.136^{* * *}$ & & $.136^{* * *}$ \\
\hline Age & & $.123^{* *}$ & & $.209 * * *$ & & $.173^{* * *}$ & & $.157^{* * *}$ & & $.171^{* * *}$ \\
\hline SES & & $-.087^{*}$ & & $-.119 * *$ & & $-.151^{* * *}$ & & $-.093^{*}$ & & $-.117^{* * *}$ \\
\hline $\begin{array}{l}\text { Education ( } 0=\text { no higher } \\
\text { education) }\end{array}$ & & $-.085 *$ & & $-.082 *$ & & -.021 & & $-.086^{*}$ & & $-.079 *$ \\
\hline Origin ( $0=$ Belgian) & & -.010 & & -.012 & & -.017 & & -.005 & & -.012 \\
\hline \multicolumn{11}{|l|}{ Victimization $(0=n o)$} \\
\hline Direct victim & & .072 & & .046 & & .027 & & $.113^{* *}$ & & .059 \\
\hline Indirect victim & & -.009 & & .014 & & .020 & & -.027 & & -.058 \\
\hline Adjusted $R^{2}$ & .062 & .089 & .087 & .153 & .058 & .117 & .094 & .151 & .191 & .256 \\
\hline F Change & $16.518^{* * *}$ & $3.994 * * *$ & $23.184^{* * *}$ & $8.818^{* * *}$ & $15.553 * * *$ & $7.695^{* * *}$ & $25.411 * * *$ & $7.731 * * *$ & $56.641 * * *$ & $9.728 * * *$ \\
\hline
\end{tabular}

Note. $N$ varied between 701 and $708 ;{ }^{*} p<.05,{ }^{* *} p<.01, * * * p<.001$. 